\title{
Dietary success of a 'new' key fish in an overfished ecosystem: evidence from fatty acid and stable isotope signatures
}

\author{
M. G. van der Bank ${ }^{1}$, A. C. Utne-Palm², K. Pittman², A. K. Sweetman ${ }^{3}$, \\ N. B. Richoux ${ }^{4}$, V. Brüchert ${ }^{5}$, M. J. Gibbons ${ }^{1, *}$ \\ ${ }^{1}$ Department of Biodiversity and Conservation Biology, University of the Western Cape, Private Bag X17, Bellville 7535, \\ South Africa \\ ${ }^{2}$ Department of Biology, University of Bergen, PO Box 7803, 5020 Bergen, Norway \\ ${ }^{3}$ Norwegian Institute for Water Research, Regional Office Bergen, Thormøhlensgate 53D, 5006 Bergen, Norway \\ ${ }^{4}$ Department of Zoology and Entomology, Rhodes University, Grahamstown 6140, South Africa \\ ${ }^{5}$ Department of Geology and Geochemistry, Stockholm University, 10691 Stockholm, Sweden
}

\begin{abstract}
The bearded goby Sufflogobius bibarbatus has become a key component of the pelagic food web off Namibia following the crash in pelagic fish populations during the 1970s, and its biomass is increasing despite significant predation pressure and apparent life-history constraints. The integrated feeding of the bearded goby was studied from samples collected during April 2008, using stable isotope ratios $\left(\delta^{13} \mathrm{C}, \delta^{15} \mathrm{~N}, \delta^{34} \mathrm{~S}\right)$ and fatty acids, to resolve conflict amongst previous dietary studies based on gut-content analysis and to understand how diet could influence its success within the region. Isotopes of carbon and nitrogen suggest that the now abundant jellyfish could contribute up to $74 \%$ of the diet, and $\delta^{34} \mathrm{~S}$ signatures indicate that the diatom- and bacteria-rich sulphidic sediments on the central shelf may contribute around $15 \%$ to the diet. Fatty acid analyses provided support for sulphur bacterial and jellyfish-feeding amongst gobies, and further suggest that small gobies fed more on zooplankton while large gobies fed more on sedimented diatoms. Both data sets suggest that ontogenetic changes in diet were linked to changes in habitat: pelagic when small, more demersal when large. The study highlights the value of using multiple tracers in trophic studies and indicates that the dietary flexibility of the bearded goby, in conjunction with its behaviour and physiology, likely contributes to its success within the northern Benguela ecosystem.
\end{abstract}

KEY WORDS: Benthic-pelagic coupling - Keystone species · Disturbed ecosystem · Feeding · Aequorea forskalea · Chrysaora fulgida

Resale or republication not permitted without written consent of the publisher

\section{INTRODUCTION}

The northern Benguela ecosystem has undergone a number of profound changes over the last few decades (Heymans et al. 2004). Sardines Sardinops sagax were the most abundant pelagic fish species in the region during the 1960s (Boyer \& Hampton 2001), but their populations crashed off Namibia during the 1970s due to a combination of overfishing and environmental change (Boyer et al. 2001, Cury \& Shannon 2004). Sar- dines were replaced by several other fishes, including horse mackerel Trachurus trachurus capensis and the bearded goby Sufflogobius bibarbatus, and to a much lesser extent by anchovy Engraulis encrasicolus (Cury \& Shannon 2004). Many higher predators (including piscivorous fishes, seabirds and seals) that had once fed on sardines started to feed on gobies instead (Crawford et al. 1985). Recently, the effects of 'fishing down the marine food web' (Pauly et al. 1998) appear to have resulted in an increase in the biomass of jelly- 
fish Chrysaora fulgida (Reynaud, 1830) and Aequorea forskalea (Forskål, 1775) (Bakun \& Weeks 2006, Lynam et al. 2006). These jellyfish have changed the transfer and flow of energy through the system, with most energy now thought to be channelled from jellyfish directly to the detrital food web (Heymans et al. 2004). The scarcity of sardines has also resulted in an increased sedimentation of primary production (Bakun \& Weeks 2006), which contributes to increased regional anoxia (Monteiro et al. 2006).

Sufflogobius bibarbatus is an unlikely 'winner' in the changed ecosystem off Namibia, as it is a relatively large, slow-growing gobiid that can attain $140 \mathrm{~mm}$ total length (TL) and an age of at least 6 yr (Melo \& Le Clus 2005). Reproductive maturity is attained only at 2 to $3 \mathrm{yr}$ of age, and although it is considered to be a serial batch spawner, overall fecundity is not high (Melo \& Le Clus 2005). The species is discontinuously distributed between Southern Angola and the Eastern Cape (South Africa), with peaks in abundance mirroring the distribution of the diatomaceous mud belt off central Namibia (Staby \& Krakstad 2006). Juvenile gobies generally occur inshore of the $200 \mathrm{~m}$ isobath, while larger individuals are more common offshore (O'Toole 1978). Although S. bibarbatus displays diel vertical migration, smaller individuals are predominantly pelagic, whereas large individuals are largely demersal (D'Arcangues 1977).

Previous studies on the diet of Sufflogobius bibarbatus have been conducted using gut-content analyses of generally small sample sizes. The results of these studies are conflicting, but suggest that it is an opportunistic predator. Barber \& Haedrich (1969) noted that juvenile gobies feed primarily on diatoms, an observation in agreement with the findings of Crawford et al. (1985) and O'Toole (1978). In contrast, D'Arcangues (1977) noted that adult and juvenile gobies feed primarily on zooplankton, whilst Macpherson \& Roel (1987) highlighted that benthic infauna can form a numerically important part of the diet. Hundt (2009) has recently shown that the diet varies with the food environment, with the diet of inshore animals being dominated by diatoms and infauna, and that of offshore animals by zooplankton and benthic infauna. Cedras (2009) has shown changes in the diet that are assumed to be linked to ontogenetic changes in the habitat occupied: smaller, more pelagic individuals fed primarily on zooplankton, whilst larger, demersal animals fed mainly on benthic infauna.

Here, we used stable isotope ratios of carbon, nitrogen and sulphur in conjunction with fatty acid analyses to resolve conflicts among previous studies on the diet and trophic position of Sufflogobius bibarbatus off Namibia, and to determine whether the feeding biology of the goby might contribute to its current success within the region. Stable isotope and fatty acid signatures provide a temporally and spatially integrated view of feeding history and trophic structure (Minagawa \& Wada 1984, Peterson \& Fry 1987, Hobson et al. 1995, Pitt et al. 2007), since they reflect assimilation of the elements into the soma. Consumers differentially accumulate heavier isotopes (Peterson \& Fry 1987) resulting in a predictable trophic enrichment (fractionation) in heavy isotopes. This fractionation is negligible for $\delta^{13} \mathrm{C}$ and $\delta^{34} \mathrm{~S}$ but ranges between 3 and $4 \%$ for $\delta^{15} \mathrm{~N}$ (Minagawa \& Wada 1984, Peterson \& Fry 1987), which means that stable nitrogen ratios $\left({ }^{15} \mathrm{~N} /{ }^{14} \mathrm{~N}\right)$ can be used to determine the relative trophic level of a particular individual (Minagawa \& Wada 1984, Peterson \& Fry 1987). Stable carbon isotope ratios $\left({ }^{13} \mathrm{C} /{ }^{12} \mathrm{C}\right)$ are commonly used to provide information on the primary source of organic matter sustaining a food web (Peterson \& Fry 1987), while stable sulphur isotope ratios are commonly used to make inferences about possible links to the detrital or benthic food web (Thomas \& Cahoon 1993). Fatty acids are also valuable tools to explore trophic relationships in aquatic systems, as different food sources can display distinctive fatty acid profiles that are transferred to consumer tissues (Budge et al. 2006, Pitt et al. 2009). The combination of stable isotopes and fatty acid markers, as used here, is widely seen as the way forward in trophic investigations (e.g. El-Sabaawi et al. 2010), as each provides slightly different sets of information.

\section{MATERIALS AND METHODS}

Field sampling and study site. The study was based on samples collected from a $48 \mathrm{~h}$ anchor station off Walvis Bay between 4 and 5 April 2008, using the RV 'G. O. Sars'. This anchor station $\left(23^{\circ} 30^{\prime} \mathrm{S}, 13^{\circ} 40^{\prime} \mathrm{E}\right.$; referred to as Stn B in Supplement 1) was situated at the outer edge of the continental shelf at a depth of $\sim 180 \mathrm{~m}$. Vertical profiles of the water column were constructed from CTD (Sea-Bird SBE 19) casts and indicated that the temperature decreased from a maximum of $18^{\circ} \mathrm{C}$ at the surface to a minimum of $13^{\circ} \mathrm{C}$ at $90 \mathrm{~m}$ (remaining constant thereafter to the bottom), and that the water column was approximately isohaline throughout (35.26 PSU; A. C. Utne-Palm et al. unpubl. RV 'G. O. Sars' cruise report). Oxygen levels at the surface were close to $6 \mathrm{ml}$ dissolved oxygen (DO) $\mathrm{l}^{-1}$, and these decreased evenly to $1 \mathrm{ml}^{-1}$ at around $100 \mathrm{~m}$ : only near the seafloor did DO concentrations drop to less than $0.4 \mathrm{ml} \mathrm{l}^{-1}$ (A. C. Utne-Palm et al. unpubl. cruise report). Additional material was collected from an inshore station $\left(23^{\circ} 20^{\prime} \mathrm{S}, 14^{\circ} 12^{\prime} \mathrm{E}\right.$; referred to as Stn A in Supplement 1) at $120 \mathrm{~m}$ depth.

Fish and jellyfish (Chrysaora fulgida, Aequorea forskalea) intended for isotope and fatty acid analysis 
were hand-picked from samples collected using both a pelagic trawl (16 $\mathrm{m}$ wide, $12 \mathrm{~m}$ high) fitted with a multisampler cod-end, and a Harsta bottom trawl $(14.5 \mathrm{~m}$ wide, $4.5 \mathrm{~m}$ high; A. C. Utne-Palm et al. unpubl. cruise report). Whole individual gobies were frozen $\left(-40^{\circ} \mathrm{C}\right)$ on collection, whilst pieces of tissue from the 2 jellyfish species (oral arm tissue for C. fulgida, umbrella perimeter tissue for A. forskalea) were removed, washed with filtered ambient seawater and then frozen.

Zooplankton samples intended for isotope and fatty acid analysis were also collected at regular intervals using a MOCNESS net (mouth area $1 \mathrm{~m}^{2}$, mesh size $180 \mu \mathrm{m})$, and the contents of the cod-ends were washed into 201 buckets. Large zooplankton (adult euphausiids, pteropods and hyperiid amphipods) were hand-picked and frozen, and the remaining material was concentrated on a $100 \mu \mathrm{m}$ mesh, rinsed with filtered ambient seawater and bulk frozen.

A mini van Veen grab was used to acquire benthic sediment and infauna for isotope and fatty acid analysis. On retrieval, the contents of the mini-grab were emptied into a bucket and thoroughly mixed. Subsamples of sediment (mud) were immediately collected and frozen, whilst macro-infauna (polychaetes) were separated, individually washed with filtered ambient seawater and then frozen. Sediments were comprised of organic mud (diatoms, diatom frustules and faecal pellets) but also bivalve and gastropod shells and foraminifera, though in general animal life was not abundant (A. C. Utne-Palm et al. unpubl. cruise report).

Laboratory analyses. Gobies were measured (nearest $0.5 \mathrm{~mm}$ ), but not sexed, and lateral muscle tissue was removed whilst still frozen. Bulk-frozen zooplankton samples were thawed and passed through a nested series of sieves with meshes of 1000, 500, 250 and $150 \mu \mathrm{m}$, and each size class of mixed zooplankton was analysed separately. The taxonomic composition of each size class is shown in Table 1, but in general, samples were dominated by copepods and juvenile euphausiids. All samples including sediments, individual large zooplankton, infaunal polychaetes and jellyfish were freeze-dried prior to isotope and fatty acid analyses.

To limit $\delta^{13} \mathrm{C}$ bias due to intra- and inter-specific variability in lipid content (DeNiro \& Epstein 1977), lipids were removed from isotope samples using a solution of chloroform:methanol:water $(2: 1: 0.8, \quad \mathrm{v}: \mathrm{v}: \mathrm{v})$ following the method of Bligh \& Dyer (1959). Inorganic carbon was removed from zooplankton and sediment samples by washing the freeze-dried samples with $2 \mathrm{~N} \mathrm{HCl}$, rinsing with distilled water and re-drying at $35^{\circ} \mathrm{C}$. While acidification artefacts on $\delta^{15} \mathrm{~N}$ values cannot be ignored (Bunn et al. 1995), freeze-drying effects are likely to be minimal, as shown by Hobson et al. (1997). The samples (see Table 2 for details of sample size) were combusted in a Flash EA 1112 series elemental analyser at the University of Cape Town, South Africa. The gasses were passed to a Delta Plus XP isotope ratio mass spectrometer (IRMS) via a Conflo III gas control unit. Nitrogen and carbon are expressed relative to atmospheric nitrogen $\left(\mathrm{N}_{2}\right)$ and Vienna Pee-Dee Belemnite (VPDB), respectively.

Since the material demands for the measurement of $\delta^{34} \mathrm{~S}$ are high, it was necessary to pool samples from both the inshore and offshore stations. Freeze-dried, ground, and chemically untreated sediment, jellyfish, zooplankton and fish tissue were analysed by conventional GC-IRMS on a Delta Plus IRMS at Stockholm University: samples were combusted with 5 -fold weight excess of vanadium pentoxide. Sulphur is expressed relative to Vienna-Canyon Diablo Troilite (VCDT) and iron sulphide.

All isotope ratios are reported in standard delta notation according to the formula: $\delta \mathrm{Z}=\left(R_{\text {sample }} / R_{\text {standard }}-1\right) \times$ 1000 , where $\delta Z$ denotes the standardised isotope signature $\left(\delta^{13} \mathrm{C}, \delta^{15} \mathrm{~N}\right.$ or $\left.\delta^{34} \mathrm{~S}\right)$, and $R$ represents the ratio of the heavier to lighter isotope $\left({ }^{13} \mathrm{C}:{ }^{12} \mathrm{C},{ }^{15} \mathrm{~N}:{ }^{14} \mathrm{~N}\right.$ or $\left.{ }^{34} \mathrm{~S}:{ }^{32} \mathrm{~S}\right)$ in the sample and standard, respectively.

Table 1. Taxonomic composition and abundance of mixed zooplankton of different sizes $(\mu \mathrm{m})$ used for stable isotope analyses. Values are expressed as percentage (\%) of the total number of individuals in a particular sample

\begin{tabular}{|c|c|c|c|c|c|c|c|c|c|}
\hline $\begin{array}{l}\text { Size } \\
\text { class }\end{array}$ & Copepods & $\begin{array}{c}\text { Juvenile } \\
\text { euphausiids }\end{array}$ & $\begin{array}{l}\text { Fish } \\
\text { eggs }\end{array}$ & Chaetognaths & $\begin{array}{l}\text { Bivalve } \\
\text { larvae }\end{array}$ & $\begin{array}{l}\text { Gastropod } \\
\text { larvae }\end{array}$ & $\begin{array}{c}\text { Echinoderm } \\
\text { larvae }\end{array}$ & Cumaceans & Medusae \\
\hline 1000 & 66.3 & 26.0 & 0 & 7.7 & 0 & 0 & 0 & 0 & 0 \\
\hline 1000 & 63.9 & 36.1 & 0 & 0 & 0 & 0 & 0 & 0 & 0 \\
\hline 1000 & 40.5 & 59.5 & 0 & 0 & 0 & 0 & 0 & 0 & 0 \\
\hline 500 & 84.5 & 1.4 & 0 & 0 & 0 & 0 & 0 & 8.5 & 5.6 \\
\hline 500 & 96.0 & 0.9 & 0.6 & 2.3 & 0.2 & 0 & 0 & 0 & 0 \\
\hline 500 & 98.7 & 0.4 & 0.4 & 0.4 & 0 & 0 & 0 & 0 & 0 \\
\hline 500 & 80.4 & 15.0 & 1.8 & 0 & 0 & 0 & 0 & 2.9 & 0 \\
\hline 250 & 70.0 & 0 & 0 & 0 & 22.1 & 0.2 & 0 & 2.9 & 0 \\
\hline 250 & 100.0 & 0 & 0 & 0 & 0.0 & 0 & 0 & 0 & 0 \\
\hline 150 & 85.0 & 0 & 0 & 0 & 14.2 & 0.6 & 0.2 & 0 & 0 \\
\hline 150 & 100.0 & 0 & 0 & 0 & 0 & 0 & 0 & 0 & 0 \\
\hline
\end{tabular}


Table 2. Sample sizes (n and mean dry weight, DW) analysed for $\delta^{13} \mathrm{C}, \delta^{15} \mathrm{~N}, \delta^{34} \mathrm{~S}$ and fatty acid signatures. MZ 150-1000: mixed zooplankton of sizes $150-1000 \mu \mathrm{m}$

\begin{tabular}{|c|c|c|c|c|c|c|}
\hline \multirow[t]{2}{*}{ Sample } & \multicolumn{2}{|c|}{ Stable isotopes $(\mathrm{C}, \mathrm{N})^{\mathrm{a}}$} & \multicolumn{2}{|c|}{ Stable isotopes $(\mathrm{S}, \mathrm{C}, \mathrm{N})^{\mathrm{b}}$} & \multicolumn{2}{|c|}{ Fatty acids -} \\
\hline & $\mathrm{n}$ & Mean DW (mg) & $\mathrm{n}$ & Mean DW (mg) & $\mathrm{n}$ & Mean DW (mg) \\
\hline Sediment & 2 & $5.9 \pm 0.01$ & 3 & $5.31 \pm 0.40$ & $2+8^{\mathrm{c}}$ & $196.38 \pm 52.01$ \\
\hline Pteropod shells & 5 & $0.63 \pm 0.04$ & - & - & 6 & $130.94 \pm 49.39$ \\
\hline Amphipods & - & - & - & - & 2 & $33.25 \pm 1.41$ \\
\hline Pteropods & 4 & $0.65 \pm 0.02$ & _- & - & 9 & $159.93 \pm 53.86$ \\
\hline Adult euphausiids & 6 & $0.63 \pm 0.05$ & - & - & 6 & $209.13 \pm 83.54$ \\
\hline MZ 150-1000 & & & 8 & $5.47 \pm 0.41$ & & \\
\hline MZ 150 & _- & _- & & & 2 & $44.40 \pm 24.74$ \\
\hline MZ 200 & 2 & $0.63 \pm 0.02$ & & & 2 & $59.74 \pm 10.94$ \\
\hline MZ 250 & - & - & & & 2 & $130.26 \pm 28.47$ \\
\hline MZ 500 & 4 & $0.64 \pm 0.03$ & & & 4 & $123.42 \pm 50.25$ \\
\hline MZ 1000 & 8 & $0.63 \pm 0.02$ & & & 5 & $189.89 \pm 23.74$ \\
\hline Aequorea forskalea & 11 & $1.07 \pm 0.61$ & 3 & $5.45 \pm 0.66$ & 9 & $373.59 \pm 98.90$ \\
\hline Chrysaora fulgida & 11 & $0.99 \pm 0.30$ & 5 & $5.54 \pm 0.42$ & $22^{\mathrm{c}}$ & $261.01 \pm 75.50$ \\
\hline Gobies & & & 7 & $5.80 \pm 0.34$ & & \\
\hline Goby large & 15 & $0.65 \pm 0.03$ & & & 20 & $35.21 \pm 11.12$ \\
\hline Goby medium & 21 & $0.64 \pm 0.03$ & & & 20 & $68.39 \pm 28.48$ \\
\hline Goby small & 41 & $0.64 \pm 0.04$ & & & 20 & $179.61 \pm 51.51$ \\
\hline
\end{tabular}

For fatty acid analysis, samples of $>20 \mathrm{mg}$ of homogenised, freeze-dried fish white muscle, jellyfish tissue, zooplankton and sediment (insufficient polychaete material was available) were preserved in $2 \mathrm{ml}$ chloroform under nitrogen at $-20^{\circ} \mathrm{C}$. The methods used for total lipid extractions and transesterification follow Budge et al. (2006) using 23:0 (tricosanoic acid $\geq 98.5 \%$ GC; FLUKA) as an internal standard. Fatty acid methyl esters (FAMEs) of total extracted lipids suspended in hexane were injected ( $1 \mu$ l aliquots) into a gas chromatograph (Hewlett Packard 5890 series $\Pi$, equipped with a ZB-Waxplus 320 column), with helium as the carrier gas. The injector and detector temperatures were maintained at $250^{\circ} \mathrm{C}$ and $260^{\circ} \mathrm{C}$, respectively, and the oven was set at $150^{\circ} \mathrm{C}$ for the first $5 \mathrm{~min}$, raised to $225^{\circ} \mathrm{C}$ at $2.5^{\circ} \mathrm{C} \mathrm{min}^{-1}$ and held for $5 \mathrm{~min}$. FAME peaks were integrated using ClarityLite 2.6.2 software, and identified by comparison with known standards (polyunsaturated fatty acid, PUFA no. 1 and a 37 component FAME mix; Supelco). Each fatty acid was measured as a proportion of the total identified fatty acids (\% TFA) and quantitatively as $\mu \mathrm{g}$ fatty acid $\mathrm{mg}^{-1}$ dry weight (DW).

Fatty acids that are required for the biological functioning of membranes and organs but are not effectively synthesised de novo by animals, termed the essential fatty acids (EFAs), include the PUFAs 20:5 03 ,

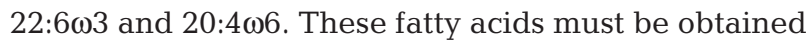
from the diet, and as such are commonly used as biomarkers for algal consumption (Budge et al. 2006). There is some uncertainty with regards to the discriminatory power of such biomarkers measured in total lipid fractions in metazoan consumers, especially since no single fatty acid is exclusive to any particular algal group. However, as the phytoplankton community in the Benguela upwelling region is dominated first by diatoms and then dinoflagellates (Fréon et al. 2009), we utilised 2 independent ratio markers to assess the prevalence of diatoms in the goby diet: $\Sigma(16: 1 \omega 7+$

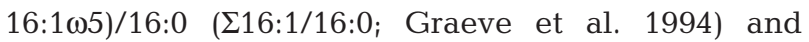
20:5 $\omega 3 / 22: 6 \omega 3$ (Parrish et al. 2000). The reverse ratio of $22: 6 \omega 3 / 20: 5 \omega 3$ was used to assess the relative dominance of dinoflagellates relative to diatoms (Parrish et al. 2000). Bacterial fatty acids (BAFAs) include oddnumbered carbon chains and iso- (i-) and anteiso- (ai-) branched forms (Budge \& Parrish 1998), and the sums of long chain monounsaturated fatty acids (MUFAs, $\Sigma[20: 1 \omega 9+22: 1 \omega 11])$ were used to indicate potential consumption of calanoid copepods $(\Sigma[20: 1+22: 1]$; Sargent \& Falk-Petersen 1988).

Statistical methods. For both stable isotope and fatty acid analyses, gobies were categorised as small $(<57 \mathrm{~mm})$, medium (58 to $90 \mathrm{~mm}$ ) and large (>90 mm) based on a visual inspection of a $\delta^{13} \mathrm{C}$ and $\delta^{15} \mathrm{~N}$ versus total length plot (Fig. 1) of goby signatures. The sample sizes of each group used for both analyses are summarised in Table 2. While we acknowledge the circularity of the methods used to delimit size classes here, there is a clear relationship between age and length (Melo \& Le Clus 2005) and there is a clear change in tracer signature over the continuous size gradient examined here.

A 1-way analysis of variance (ANOVA) was used to analyse potential differences in the $\delta^{13} \mathrm{C}$ and $\delta^{15} \mathrm{~N}$ sig- 

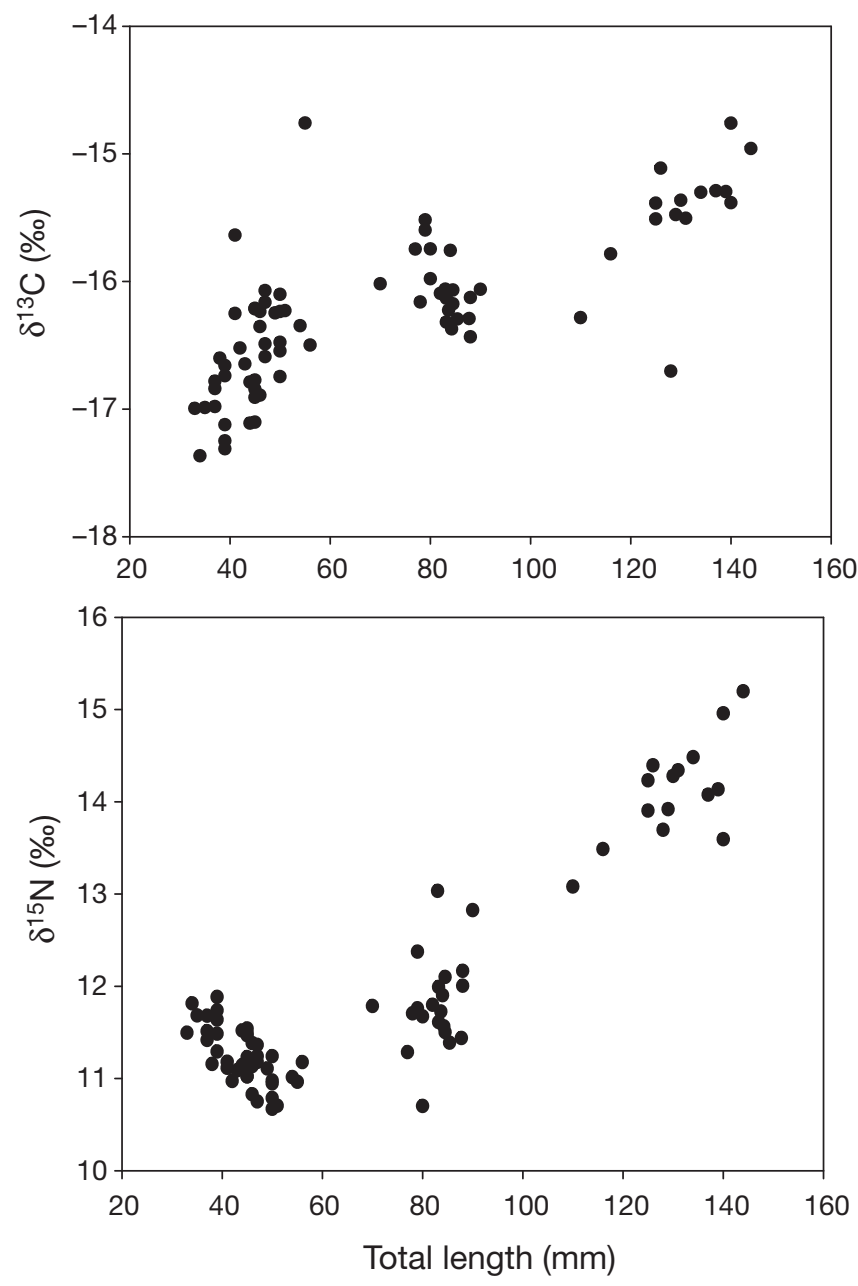

Fig. 1. Sufflogobius bibarbatus. Changes in $\delta^{13} \mathrm{C}$ and $\delta^{15} \mathrm{~N}$ signatures with size of the bearded goby off Namibia at $180 \mathrm{~m}$ depth. Small gobies: $<57 \mathrm{~mm}$ total length (TL); medium-sized gobies: 58-90 mm TL; large gobies: > $90 \mathrm{~mm}$ TL

natures among the different goby size classes. To establish from which food types gobies were deriving nutrition, we calculated ranges in isotope values expected for all food types and used these values to draw 'trophic-shift boxes' in 2-dimensional $\delta^{13} \mathrm{C}$ and $\delta^{15} \mathrm{~N}$ space. Fauna that derive $100 \%$ of their diet from jellyfish, sediment and zooplankton are expected to cluster within the trophic boxes for the respective food sources (Demopoulos et al. 2007). For these calculations, we assumed no trophic-level fractionation for $\delta^{13} \mathrm{C}$ (France \& Peters 1997), and a $+3 \%$ increase in $\delta^{15} \mathrm{~N}$ per trophic level for jellyfish, sediment and zooplankton (Demopoulos et al. 2007).

A multisource mixing model (IsoSource) was used to estimate minimum and maximum proportional contributions of potential prey items to the goby diet (Phillips $\&$ Gregg 2003). To do this, $\delta^{15} \mathrm{~N}$-corrected and uncor- rected $\delta^{13} \mathrm{C}$ faunal isotope measurements were plotted in $\delta^{13} \mathrm{C}$ and $\delta^{15} \mathrm{~N}$ space and a 5 -sided polygon drawn narrowly around the data (see Fig. S1 in the Supplement 1 at www.int-res.com/articles/suppl/m428p219_ supp.pdf). The apices of the polygon represent the average isotope signatures that must be available to support the gobies. Apices were allocated for adult euphausiids, shrimp, Aequorea forskalea, Chrysaora fulgida 1 and $C$. fulgida 2, of which $C$. fulgida 1 had lower $\delta^{13} \mathrm{C}$ and $\delta^{15} \mathrm{~N}$ signatures relative to $C$. fulgida 2 , perhaps as a consequence of natural variation. C. fulgida 1 and 2 end members were defined as possible food resources since isotope values of jellyfish of the same species can be distinct (Towanda \& Thuesen 2006, Pitt et al. 2009). Therefore, we used 2 C. fulgida end members. Isotopic signatures of gobies and food source end members were then used in the 5-source mixing model (Fig. S1), in order to calculate the proportional contributions of all food sources to goby diet (Demopoulos et al. 2007, Utne-Palm et al. 2010). Source increment was set at $1 \%$, with a tolerance level of $0.05 \%$. Spearman rank correlations (Zar 1999) with subsequent sequential Bonferroni corrections (Quinn $\&$ Keough 2002) were used to correlate fish size with prey source contributions.

To determine the contribution of benthic and pelagic food sources to the diet of Sufflogobius bibarbatus, a 2 end member linear mixing model was employed (Levin \& Michener 2002) using $\delta^{34} \mathrm{~S}$ signatures. Ultimately, the 'enriched $\delta^{34} \mathrm{~S}$ food source' (mixed zooplankton and jellyfish) was used as 1 end member and the 'reduced $\delta^{34} \mathrm{~S}$ food source' (benthic sediment containing diatoms, sulphur bacteria and/or benthic meiofauna) as the other end member. However, a precise allocation of the benthic $\delta^{34} \mathrm{~S}$ end member signature is difficult, because the process of freeze-drying removes part of the porewater hydrogen sulphide and precipitates isotopically heavy porewater sulphate. We selected 2 values to estimate the benthic contribution: an average value of $+5.75 \%$ versus VCDT was used as the isotopically light end member representing spatially pooled freeze-dried sediment containing diatoms, benthic meiofauna and sulphur bacteria. An alternative value of $-15 \%$ versus VCDT was used as the second end member based on previous measurements at a shelf station at $23^{\circ} 45.5^{\prime} \mathrm{S}, 14^{\circ} 16.0^{\prime} \mathrm{E}$ in $114 \mathrm{~m}$ water depth (Dale et al. 2009). We based the use of this value on the fact that sulphur available to grazing gobies is porewater hydrogen sulphide, organic sulphur and elemental sulphur stored in sulphur bacteria, but not mineral sulphides and inorganic sulphate. The origin of the sulphides and elemental sulphur is through production by sulphate-reducing bacteria, which fractionate porewater sulphate to derive hydrogen sulphide with a value of $-15 \%$ (Dale et al. 2009). 
The fatty acid data were analysed quan-

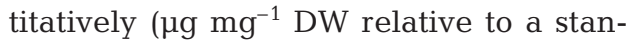
dard, 23:0) and qualitatively (as percentage of TFA), the latter being useful in situations where samples vary greatly in their TFA content. The effects of ontogeny on key fatty acids and entire fatty acid profiles of gobies were determined using a series of 1-way ANOVAs, with subsequent Bonferroni correction (Quinn \& Keough 2002) and principal component analysis (PCA), respectively, following normalisation of the quantitative fatty acid data using a mix of $\log _{10}$ and square root transformations. Relationships between the composition of potential dietary items (taxa or size classes of taxa) and gobies were also explored using non-metric multidimensional scaling (NMDS) in PRIMER v6 (Clarke \& Warwick 2001).

\section{RESULTS}

\section{Stable isotopes}

Small, medium and large gobies were significantly different from each other in terms of their $\delta^{13} \mathrm{C}(F=$ $37.55, \mathrm{p}<0.05, \mathrm{n}=41, \mathrm{n}=21$ and $\mathrm{n}=15$, respectively) and $\delta^{15} \mathrm{~N}$ signatures $(F=255, \mathrm{p}<0.05, \mathrm{n}=41, \mathrm{n}=21$ and $n=15$, respectively). Gobies became more enriched in the heavier carbon isotope as they increased in size (Fig. 1). Small gobies fed at the same average trophic level $\left(\delta^{15} \mathrm{~N}=11.24 \pm 0.05 \% \mathrm{SE}_{;} \mathrm{n}=41\right)$ as medium gobies $\left(\delta^{15} \mathrm{~N}=11.82 \pm 0.11 \%\right.$; $\left.\mathrm{n}=21\right)$, but small and medium gobies fed at a lower trophic level compared to large gobies $\left(\delta^{15} \mathrm{~N}=14.12 \pm 0.14 \%\right.$; $\mathrm{n}=$ 15; Fig. 1).

Small and medium-sized gobies were similar to Chrysaora fulgida in their $\delta^{13} \mathrm{C}$ signatures (Fig. 2). Based on $\delta^{15} \mathrm{~N}$ signatures, Aequorea forskalea fed at the same average trophic level as small and mediumsized gobies but lower than large gobies and higher than C. fulgida (Fig. 2).

Shrimp, benthic polychaetes, sediments and adult euphausiids had carbon isotope signatures closest to that of the goby. Pteropods (Cymbulia sp.) possessed similar $\delta^{15} \mathrm{~N}$-signatures compared to mixed zooplankton, which suggests that they feed at similar trophic levels (Fig. 2). However, nitrogen isotope signals indicated that pteropods feed at a lower trophic level compared to small gobies, medium gobies, benthic polychaetes and shrimp, which all appeared to feed at approximately the same average trophic level (Fig. 2).
Spatially pooled sediment had the lowest $\delta^{34}$ S signatures $\left(\delta^{34} \mathrm{~S}=5.75 \pm 0.99 \% ; \mathrm{n}=3\right)$, followed by that of gobies $\left(\delta^{34} \mathrm{~S}=16.45 \pm 0.41 \%\right.$; $\left.\mathrm{n}=7\right)$, mixed zooplankton $\left(\delta^{34} \mathrm{~S}=19.78 \pm 0.64 \% ; \mathrm{n}=8\right)$, Aequorea forskalea $\left(\delta^{34} \mathrm{~S}=21.44 \pm 0.21 \% ; \mathrm{n}=3\right)$ and Chrysaora fulgida $\left(\delta^{34} \mathrm{~S}=21.50 \pm 0.12 \% ; \mathrm{n}=7\right.$; Fig. 3$) . \delta^{13} \mathrm{C}$ and $\delta^{15} \mathrm{~N}$ signatures of sediment were $-16.35 \pm 1.10 \%$ and $6.19 \pm$ $0.37 \%$, respectively.

Based on trophic shift boxes, gobies appeared to receive only a small part of their diet from sediment, as

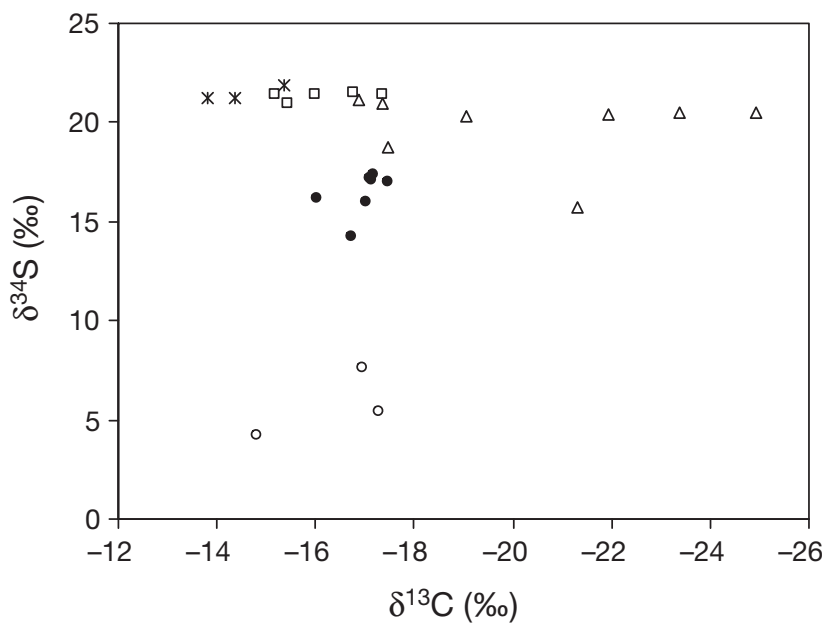

Fig. 3. Cross-plot of $\delta^{13} \mathrm{C}$ versus $\delta^{34} \mathrm{~S}$ of individual samples of sediment (open circles), Aequorea forskalea (stars), Chrysaora fulgida (open squares), mixed zooplankton (open triangles) and Sufflogobius bibarbatus (closed circles) collected off the Namibian shelf during April 2008. Modified from Utne-Palm et al. (2010) 
their $\delta^{15} \mathrm{~N}$ signatures were outside the range of the diatomaceous mud (also known to contain large sulphur bacteria and diatoms; Fig. 4). Gobies fed on Aequorea forskalea and Chrysaora fulgida, although it appeared that the very large gobies fed almost exclusively on $A$. forskalea (upper leftmost symbols in Fig. 4 and see Fig. 5) while possibly supplementing their diet with shrimp (Fig. 4).

The results of the IsoSource model indicate that the maximum contribution of Aequorea forskalea was positively correlated with fish size $(\mathrm{R}=0.91, \mathrm{p}<0.05, \mathrm{n}=$ 76; Fig. 5), with average source contributions reaching a maximum of $70.36 \%$ in large gobies (Table 3). Chrysaora fulgida with lighter $\delta^{13} \mathrm{C}$ and $\delta^{15} \mathrm{~N}$ signatures was negatively correlated with fish size $(\mathrm{R}=$ $-0.82, \mathrm{p}<0.05, \mathrm{n}=76$; Fig. 5), and potentially reached an average maximum contribution of $73.85 \%$ in small fish (Table 3).

The $\delta^{34} \mathrm{~S}$ signatures indicated that contributions of the benthic sediment (which may include diatoms and bacteria) to the diet of the goby were on average $34.2 \pm$ $2.5 \%$, if the average value of $+5.75 \%$ versus VCDT for freeze-dried sediment is used as the end member (Table 4). If an average value of $-15 \%$ versus VCDT is chosen for the biologically available sulphur fraction (see Discussion), then the dietary contribution of the benthos is $15.0 \pm 1.1 \%$ (Table 4 ).

\section{Fatty acids}

All raw qualitative (Tables S1 to S4 ) and quantitative (Tables S5 to S8) individual and summary fatty acids are presented in Supplement 1 at www.int-res.

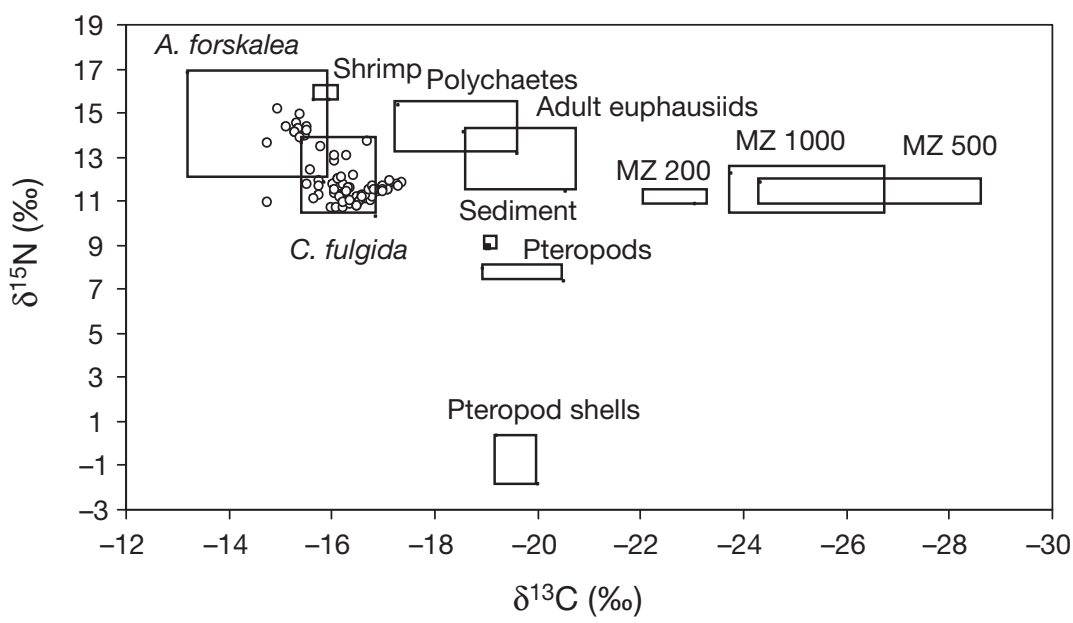

Fig. 4. Sufflogobius bibarbatus. Trophic-shift boxes of gobies collected off Namibia during 2008, related to the upper and lower limits of the $\delta^{13} \mathrm{C}$ and $\delta^{15} \mathrm{~N}$ signatures of potential prey items. A.: Aequorea; C.: Chrysaora; MZ 200-1000: mixed zooplankton of sizes $200-2000 \mu \mathrm{m}$

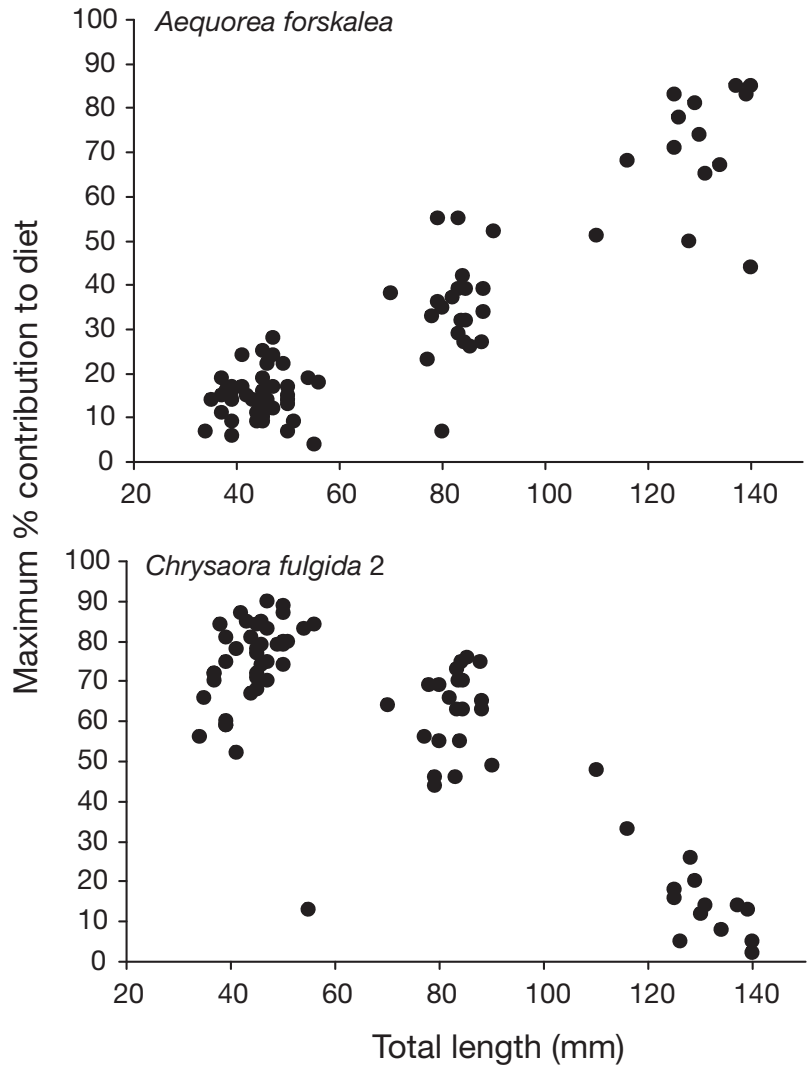

Fig. 5. Sufflogobius bibarbatus. Changes in maximum percentage contribution of Aequorea forskalea and Chrysaora fulgida 2 to the diet of bearded goby with fish size (total length, mm)

com/articles/suppl/m428p219_supp.pdf, and all essentially indicate similar patterns.

NMDS results based on fatty acid profiles suggested that gobies were not deriving nutrients from sediment or pteropod shells, but that large gobies were potentially feeding on jellyfish (Fig. 6). As a group, gobies could also be deriving nutrition from a combination of pteropods (soft tissue), amphipods, euphausiids and mixed zooplankton (Fig. 6). PCA of the quantitative fatty acid profiles of the gobies suggested that the diet of small gobies differed from that of large gobies, with medium gobies representing a transitional and variable developmental stage (Fig. 7). The PCA loadings demonstrated that the saturated fatty acids (SFAs) 14:0, 16:0 and 18:0, the MUFAs 16:1 $107,18: 1 \omega 7,18: 1 \omega 9$ and

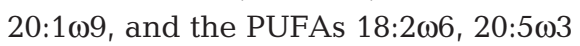
and 22:603 were strongly associated 
Table 3. Average $( \pm \mathrm{SE})$ minimum and maximum percentage contribution of different prey to the diet of Sufflogobius bibarbatus of different size, as determined from a 5 end member IsoSource model (see 'Materials and methods' for more details)

\begin{tabular}{|c|c|c|c|c|}
\hline \multirow[t]{2}{*}{ Prey source } & \multirow{2}{*}{$\begin{array}{l}\text { Fish size } \\
\quad(\mathrm{mm})\end{array}$} & \multirow[t]{2}{*}{$\mathrm{n}$} & \multicolumn{2}{|c|}{ Percent contribution } \\
\hline & & & Min. & Max. \\
\hline \multirow[t]{3}{*}{ Adult euphausiids } & $<57$ & 41 & $8.17 \pm 1.73$ & $26.85 \pm 1.87$ \\
\hline & $58-90$ & 21 & 0 & $33.14 \pm 1.93$ \\
\hline & $>90$ & 14 & $1.71 \pm 1.64$ & $18 \pm 3.89$ \\
\hline \multirow[t]{3}{*}{ Shrimp } & $<57$ & 41 & 0 & $12.44 \pm 0.62$ \\
\hline & $58-90$ & 21 & 0 & $27.05 \pm 2.2$ \\
\hline & $>90$ & 14 & $11.14 \pm 4.18$ & $58.64 \pm 4.34$ \\
\hline \multirow[t]{3}{*}{ Aequorea forskalea } & $<57$ & 41 & 0 & $14.73 \pm 0.85$ \\
\hline & $58-90$ & 21 & 0 & $35.1 \pm 2.39$ \\
\hline & $>90$ & 14 & $12.07 \pm 5.55$ & $70.36 \pm 3.68$ \\
\hline \multirow[t]{3}{*}{ Chrysaora fulgida 1} & $<57$ & 41 & $3.85 \pm 2.18$ & $29.56 \pm 2.29$ \\
\hline & $58-90$ & 21 & $3.81 \pm 1.74$ & $55.05 \pm 2.03$ \\
\hline & $>90$ & 14 & $0.79 \pm 0.79$ & $26.79 \pm 2.62$ \\
\hline \multirow[t]{3}{*}{ C. fulgida 2} & $<57$ & 41 & $44.1 \pm 1.99$ & $73.85 \pm 2.1$ \\
\hline & $58-90$ & 21 & $9.29 \pm 3.07$ & $62.48 \pm 2.21$ \\
\hline & $>90$ & 14 & 0 & $16.71 \pm 3.28$ \\
\hline
\end{tabular}

Table 4. Relative percentage dietary contribution from benthic sediment, porewater hydrogen sulphide and pelagic 'enriched $\delta^{34} \mathrm{~S}$ food sources' to the diet of gobies as calculated from a 2 end member mixing model (Scenario 1: $\delta^{34} \mathrm{~S}_{\text {sediment }}=$ $5.8 \%$ vs. VCDT; Scenario 2: $\delta^{34} \mathrm{~S}_{\mathrm{H} 2 \mathrm{~S}}=-15 \%$ vs. VCDT). See 'Materials and methods' for more details. Mean \pm SE values for benthic and 'enriched $\delta^{34} \mathrm{~S}$ food source' contributions are indicated. VCDT: Vienna-Canyon Diablo Troilite

\begin{tabular}{|c|c|c|}
\hline \multirow{2}{*}{$\begin{array}{l}\delta^{34} \mathrm{~S} \\
(\% \circ)\end{array}$} & \multicolumn{2}{|c|}{ Benthic contribution to diet } \\
\hline & Scenario 1 & Scenario 2 \\
\hline 16.0 & 37.0 & 16.3 \\
\hline 17.1 & 30.0 & 13.2 \\
\hline 17.2 & 29.8 & 13.1 \\
\hline 17.4 & 28.6 & 12.6 \\
\hline 16.2 & 35.6 & 15.6 \\
\hline 17.0 & 30.5 & 13.4 \\
\hline 14.3 & 47.6 & 20.9 \\
\hline Benthic contribution & $34.2 \pm 2.5$ & $15.0 \pm 1.1$ \\
\hline ‘Enriched pelagic' contribution & $65.8 \pm 2.5$ & $85 \pm 1.1$ \\
\hline
\end{tabular}

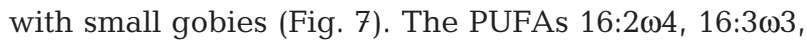

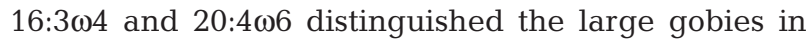
the PCA (Fig. 7). A PCA using summary fatty acid profiles of quantitative data (not shown) indicated the greatest fatty acid content (TFA, SFA, MUFA, PUFA, EFA, BAFA and $\Sigma[22: 1+20: 1])$, as well as larger ratios of the traditional dinoflagellate marker 22:6 $\omega 3 / 20: 5 \omega 3$ in small gobies, whereas traditional diatom markers $\Sigma 16: 1 / 16: 0$ and 20:5 $\omega 3 / 22: 6 \omega 3$ were elevated in the tissues of large gobies (Table S7).
No marker specific to jellyfish was identified during this study, but both gobies and jellyfish had elevated ratios of 22:6 $\omega 3 / 20: 5 \omega 3$ (Tables S7 \& S8). Aequorea forskalea and Chrysaora fulgida were proportionally high in i-17:0 (1.16 and $1.14 \%$ TFA, respectively) and 19:0 (1.27 and 1.34\% TFA, respectively) compared to other prey items (Fig. 8). Similarly, elevated proportions of these fatty acids were seen in the tissues of small, medium and large gobies (Fig. 8). Sediment was dominated by 16:0 (20.28\% TFA), $18: 1 \omega 7 \quad(14.27 \% \quad$ TFA $)$ and 16:1 107 (12.92\% TFA; Table S2). Sediment was substantially higher in ai-15:0 (3.13 to $5.41 \%$ TFA), $24: 0$ (1.29 to $5.59 \%$ TFA), $16: 1 \omega 7$ (6.24 to $12.92 \%$ TFA), $18: 1 \omega 7$ (6.66 to $14.27 \%$ TFA; Tables S1 \& S2) and BAFA (12.06 to $14.3 \%$ TFA; Tables S3 \& S4) when compared to most other food sources.

\section{DISCUSSION}

\section{Herbivory or detritivory?}

The $\delta^{34}$ S results suggest that spatially pooled benthic sediment contributed to the diet of the goby. The source apportionment depends critically on the isotope composition of benthic endmembers and potential sulphur isotope trophic shifts. It is difficult to assign a specific sulphur isotope value to the benthic diet based on a bulk measurement of freeze-dried sediment. Only a fraction of the freeze-dried sediment likely comprises the food source for gobies considering that the diatomaceous sediment contains iron sulphide mineral grains and seawater sulphate that will pass unused through the gut of the goby. Therefore, only selective organic sulphur compounds and sulphur stored in bacterial biomass form part of the sulphur in the goby diet. Based on individual sulphur species isotope studies, the sulphur isotope composition of these fractions is significantly lighter and varies between -10 and $-20 \%$ in the top $3 \mathrm{~cm}$ of sediment (Dale et al. 2009). Such a light sulphur isotope diet diminishes the benthic diet contribution. The Namibian shelf sediment is known to contain diatoms and sulphur-storing bacteria such as Thiomargarita sp. (Schulz et al. 1999), and previous studies have all highlighted diatoms as being major components of the diet of gobies collected inshore along the Namibian coast (Barber \& Haedrich 1969, O'Toole 1978, Crawford et al. 1985, Hundt 2009). The 


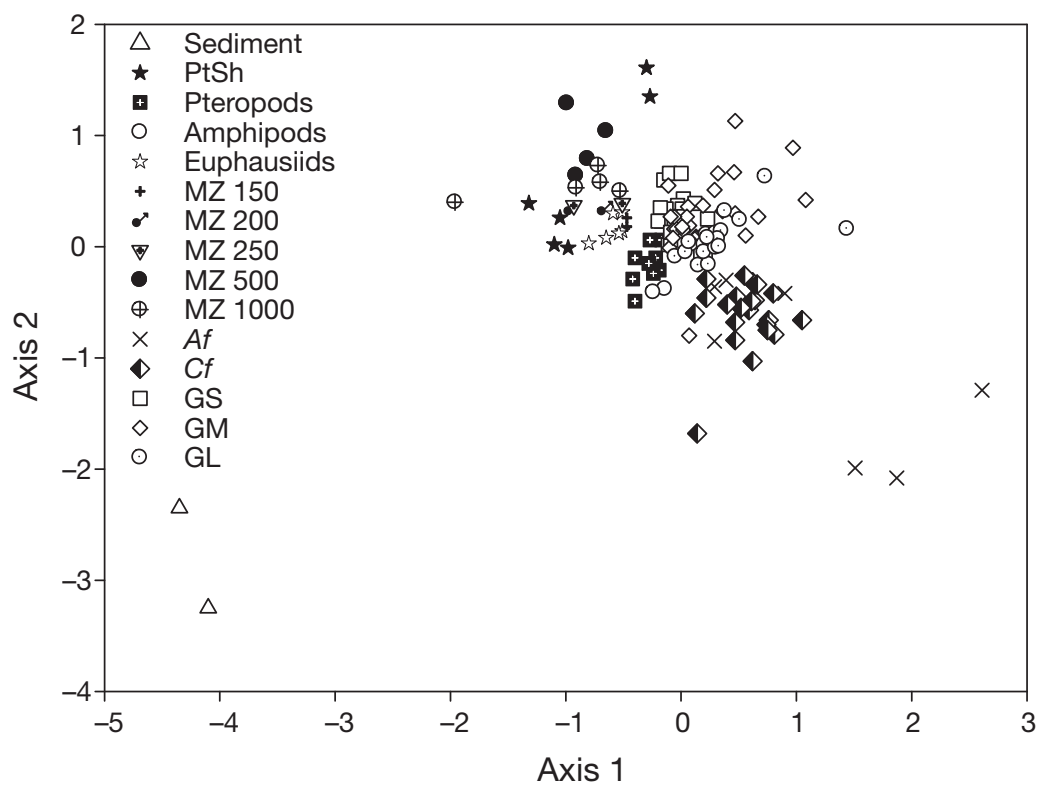

Fig. 6. Sufflogobius bibarbatus. Non-metric multidimensional scaling (NMDS) ordination of the qualitative individual fatty acid profiles of bearded goby and its potential prey. PtSh: pteropod shells; MZ 150-1000: mixed zooplankton sized 150-1000 $\mu \mathrm{m} ;$ Af: Aequorea forskalea; Cf: Chrysaora fulgida; GS: small gobies; GM: medium gobies; GL: large gobies. All samples were collected at the offshore station, but $C$. fulgida are from the inshore station
$\Sigma 16: 1 / 16: 0$ and 20:5 $13 / 22: 6 \omega 3$ compared to small and medium gobies (Fig. 8, Table S7). These data suggest that large gobies ingested more diatom-rich sediment than small gobies, which is in agreement with ontogenetic changes in vertical habitat use (D'Arcangues 1977). Although it is possible that large gobies may have derived their algal fatty acids from ingesting zooplankton that were high in diatom markers, absolute concentrations of the copepod markers 20:1 19 and 22:1611 showed a general decrease with increasing goby size (Table S5). As such, small and medium-sized gobies may have acquired fatty acids characteristic of diatoms by feeding on zooplankton as well as benthic sediments.

Sediment was dominated by 16:0,

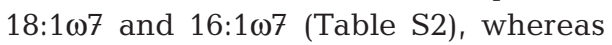
branched fatty acids such as i-17:0 typically found in sulphate-reducing bacteria (Taylor \& Parkes 1983, Zhang et al. 2002) were minor components. Sediment fatty acid profiles in the Northern Benguela ecosystem are consistent with those of Thioploca sp., Beggiatoa sp. and other short, widely spaced gill rakers of gobies render them unable to filter feed on diatoms directly in the water column (Utne-Palm et al. 2010), in contrast to other specialist filter feeding fishes such as sardine (van der Lingen et al. 2009). Considering that the contribution of the benthic diet may be closer to $15 \%$, the benthic C and $\mathrm{N}$ contribution to the goby diet is so small that it does not affect the $\delta^{15} \mathrm{~N}$ and $\delta^{13} \mathrm{C}$ values of the gobies significantly. This interpretation fits well with the observation that the $\delta^{15} \mathrm{~N}$ values of the sediment, which were similar to the observations ( -20 to $-21 \%$, and 5.5 to $7 \%$, respectively) recorded by Struck et al. (2002) off Namibia (but see below), are very different from each other.

Results of trophic sulphur isotope shifts have been variable and showed fractionations between -3 and $+4 \%$ o for individual taxa (Connolly et al. 2004). On average, however, no significant isotope shifts have been observed when multiple taxa were considered (McCutchan et al. 2003, Connolly et al. 2004). Support for minor trophic isotope shifts also come from the small variation of sulphur isotope values for all zooplankton and jellyfish $(20.5 \pm 1.6 \%, \mathrm{n}=19)$, which, despite their different trophic levels, all have sulphur isotope values close to the sulphur isotope composition of seawater sulphate $(20.7 \%$ o).

Analyses of the fatty acids showed that the tissues of large gobies contained greater diatom marker ratios

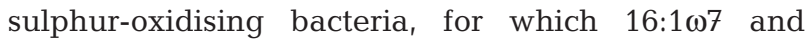
18:1 17 have been proposed as signature biomarkers in $\mathrm{H}_{2} \mathrm{~S}$-rich marine sediments (Jacq et al. 1989, McCaffrey et al. 1989, Zhang et al. 2005). Besides 16:107 and 18:1 $\omega 7$, ai-15:0 and 24:0 were also found in higher proportions in sediment compared to animal prey (Tables S1 \& S2), suggesting that gobies were opportunistic detritivores deriving these fatty acids from bacteria in the sediment.

\section{Carnivory}

Mixed zooplankton (primarily copepods and juvenile euphausiids) were not significantly assimilated by gobies according to the stable carbon and nitrogen analyses (Fig. 4), contrasting with earlier stomach content data (D'Arcangues 1977, O'Toole 1978, Macpherson \& Roel 1987). In our study, euphausiids were generally of secondary importance, and their consumption was not significantly correlated with goby size (Fig. 5a); these findings are in Hundt (2009).

Whereas isotopes of carbon and nitrogen could not identify links between gobies and zooplankton, fatty acid analyses (particularly the quantitative data) suggested that gobies may have derived much of their agreement with those of both Cedras (2009) and 

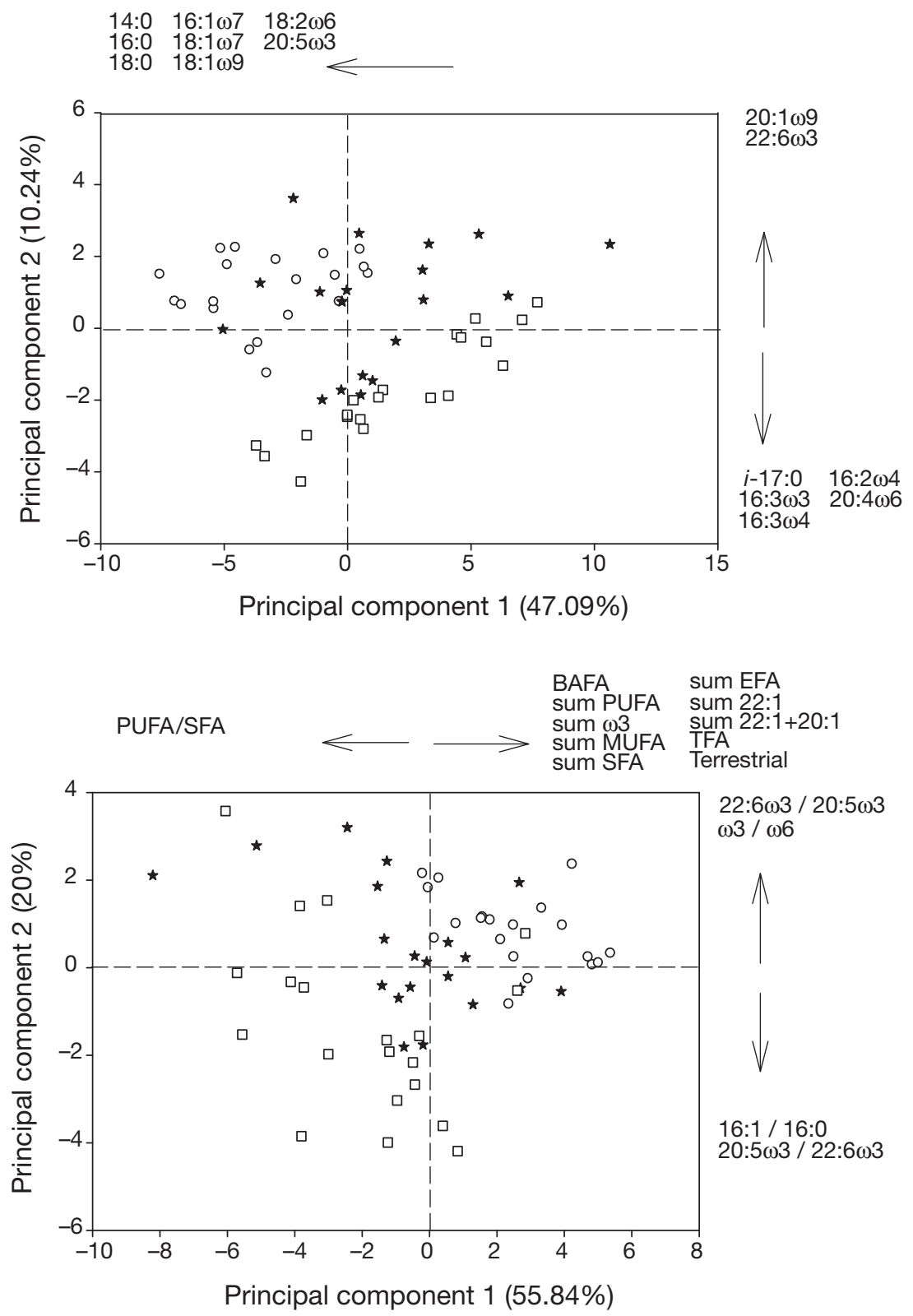

Fig. 7. Sufflogobius bibarbatus. Principal component plots of the transformed quantitative fatty acid composition $\left(\mu \mathrm{g} \mathrm{mg}^{-1}\right.$ dry weight, DW) of small (circles), medium (stars) and large (squares) gobies collected off the coast of Namibia during April 2008. (a) All individual fatty acids, (b) summary fatty acids. Arrows running parallel to axes represent the most influential fatty acids with loading values greater than 0.2. Dashed lines denote the origin. Percentage values represent the proportion of the variance explained by each principal component. BAFA: bacterial fatty acid; MUFA: monounsaturated fatty acid; PUFA: polyunsaturated fatty acid; SFA: saturated fatty acid; EFA: essential fatty acid

absolute concentrations of 20:1 $\omega 9$ and 22:1611 (Table S5). Cedras (2009) recently showed a negative relationship between goby size and the frequency of copepod consumption, which he suggested was a reflection of the more pelagic habitat of younger gobies.

Based on isotopic data, the diet of small gobies was dominated by Chrysaora fulgida, with depleted $\delta^{13} \mathrm{C}$ and $\delta^{15} \mathrm{~N}$-signatures (maximum contribution of $73.85 \%$ ), while the diet of large gobies was dominated by Aequorea forskalea (70.36\%; Table 3). Trophic links have not previously been made between gobies and jellyfish. While it is possible that this simply reflects the recent nature of the increases in jellyfish biomass, it more likely reflects the fast digestion rate of jellyfish tissue (Arai et al. 2003, Arai 2005) and prolonged and inefficient sample storage (Arai 2005). Jellyfish had very low lipid contents, although both gobies and jellyfish had elevated ratios of the

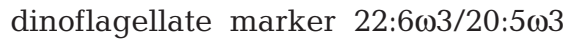
(Tables S7 \& S8), which agrees with dietary observations by Flynn \& Gibbons (2007). It is thus possible that the dinoflagellate fatty acid signature present in Sufflogobius bibarbatus is an indirect reflection of their consumption of jellyfish, as gobies are unlikely to graze directly on dinoflagellates in the water column. Both jellyfish species were proportionally higher in i-17:0 and 19:0 when compared to other prey items (Fig. 8), as were goby tissues (Fig. 8). These specific fatty acids, along with the multivariate analysis of the fatty acid profiles (Fig. 6), together suggest that gobies could have been feeding on jellyfish in very high quantities to compensate for the low nutritional value of this easily digested tissue (Arai et al. 2003). Although the close association between jellyfish and gobies in the water column (Utne-Palm et

EFAs from zooplankton, of which the largest fractions contained mean EFA totals $>30 \mu \mathrm{g} \mathrm{mg} \mathrm{mg}^{-1}$ DW (Table S7). Small gobies had greater dietary contributions from copepods compared to medium and large gobies, as indicated by their significantly higher al. 2010) may help the non-specialist gobies avoid other predators while feeding on abundant prey, we should be careful in our interpretation because it is equally possible that the gobies were eating moribund jellyfish on the seafloor. 


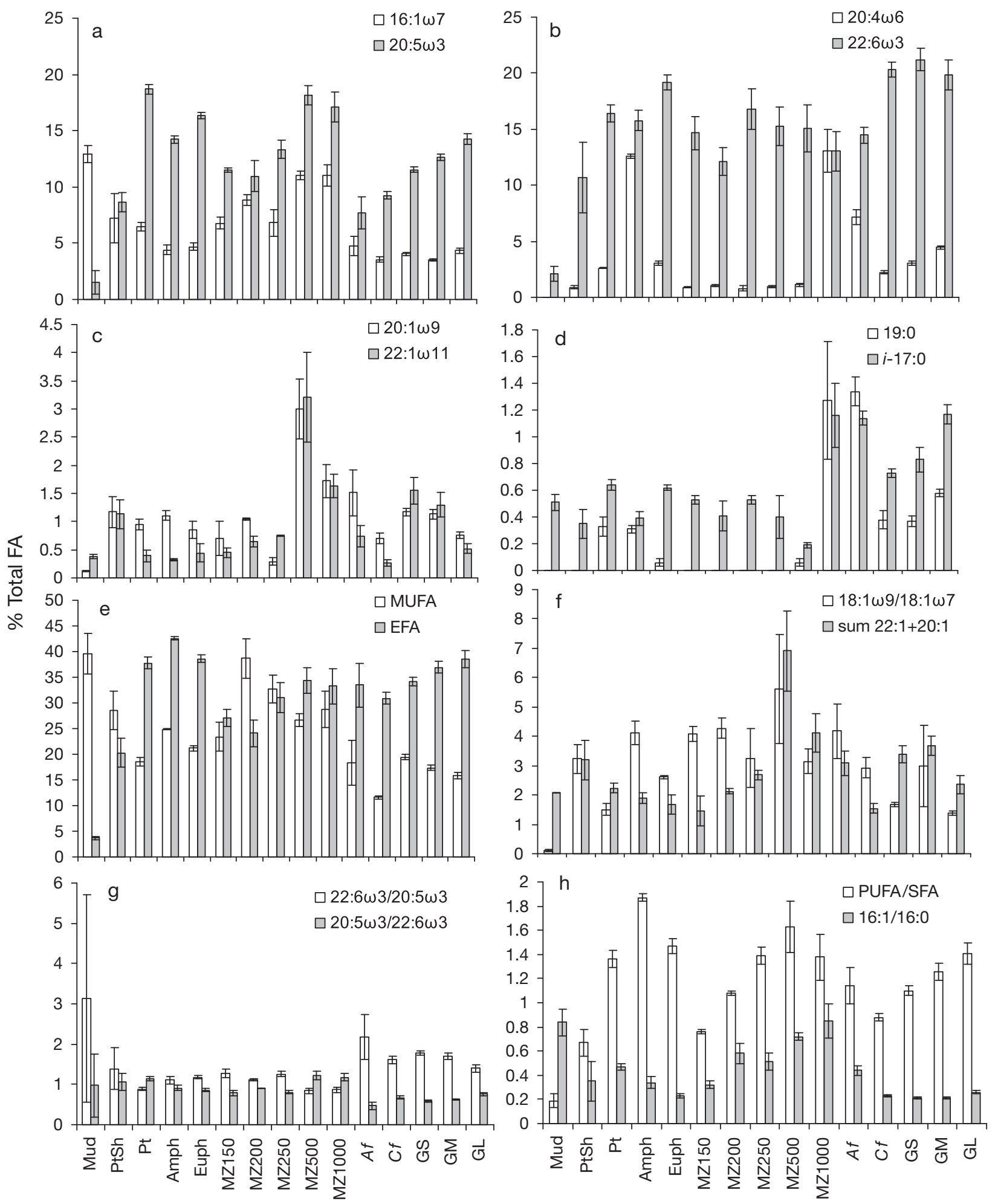

Fig. 8. Sufflogobius bibarbatus. Qualitative comparison (\% total fatty acids) of the key fatty acids: (a) 16:1 $1 \omega 7$ and $20: 5 \omega 3$; (b)

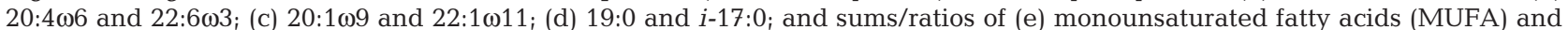

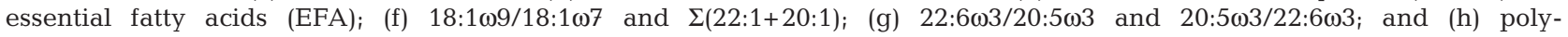
unsaturated/saturated fatty acids (PUFA/SFA) and $\Sigma$ 16:1/16:0 of gobies and their potential food sources. Values are mean \pm SE. PtSh: pteropod shells; Pt: pteropods; Amph: amphipods; Euph: adult euphausiids; MZ150-1000: mixed zooplankton of sizes 150-1000 $\mu \mathrm{m} ;$ Af: Aequorea forskalea; Cf: Chrysaora fulgida; GS: small gobies; GM: medium gobies; GL: large gobies. All samples were collected at the offshore station, but $C$. fulgida were from the inshore station 


\section{Ontogenetic shift in goby diet}

There appear to be gradual changes in the diet of the goby as it increases in size: small gobies fed primarily on Chrysaora fulgida with depleted $\delta^{13} \mathrm{C}$ and $\delta^{15} \mathrm{~N}$ signatures and supplemented their diet with prey enriched in $\delta^{13} \mathrm{C}$ and $\delta^{15} \mathrm{~N}$, including C. fulgida, Aequorea forskalea and adult euphausiids (Fig. 5, Table 3$)$. Fatty acid data suggest that small gobies also

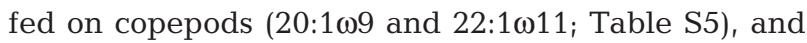
as they grew in size they developed a diet dominated by $A$. forskalea, supplemented by $C$. fulgida, adult euphausiids (Fig. 5, Table 3) and diatom (sediment) input (Fig. 8g,h, Tables S5 \& S7).

Whilst caution should be exercised in the interpretation of signature variations with size, which might be artefacts arising from size-dependent effects on metabolic turnover or accumulation of specific biochemical components (Rossi et al. 2004), a number of studies have shown ontogenetic changes in the diet of gobies (Gibson 1970, del Norte-Campos \& Temmings 1994, Maruyama et al. 2001, Sorensen \& Hobson 2005). These changes have been attributed to shifts in metabolic demands (Levy 1990), morphology, habitat, prey availability (Grossman 1980) or behaviour (Grossman et al. 1980). Cedras (2009) highlighted the importance of habitat change, noting that smaller gobies fed primarily on plankton, whilst larger individuals fed mostly in the benthos. Small gobies are more pelagic, frequently migrating vertically in the water column (D'Arcangues 1977, Staby \& Krakstad 2006). Large gobies are primarily demersal and migrate infrequently (D'Arcangues 1977, Staby \& Krakstad 2006), which coincides with the increased dietary contribution from benthic diatoms but decreased contributions from pelagic copepods, as indicated by the fatty acid results (Tables S5 \& S7).

The apparent ontogenetic change in the composition of the jellyfish component (Chrysaora fulgida to Aequorea forskalea) of the goby diet coincides with cross-shelf distribution patterns: $C$. fulgida tends to be more abundant than $A$. forskalea closer to the shore, whilst the opposite situation is found offshore (as here) (Sparks et al. 2001, Utne-Palm et al. 2008). Small gobies are more common closer to the coast than larger fish (O'Toole 1978) and likely move offshore with increasing age and size, as do many other demersal species within the region (e.g. Gordoa et al. 1995). Interestingly, both species of jellyfish are found throughout the water column but reach highest densities near the surface (Buecher et al. 2001, Sparks et al. 2001), which suggests either that large gobies scavenge moribund jellyfish on the seafloor (as e.g. Lebrato \& Jones 2009), or that they move into near surface waters to consume them.

\section{CONCLUSIONS}

Isotopic comparisons among gobies, anchovy and sardines in the Benguela ecosystem suggest that Sufflogobius bibarbatus feeds at the same average trophic level as anchovy $\left(\delta^{15} \mathrm{~N} \approx 12 \%\right.$, C. D. van der Lingen \& T. Miller pers. comm.), but that both gobies $\left(\delta^{15} \mathrm{~N} \approx\right.$ $12 \%$ ) and anchovy feed at a higher trophic level than sardines $\left(\delta^{15} \mathrm{~N} \approx 9.5 \%\right.$, C. D. van der Lingen \& T. Miller pers. comm.). Anchovies (van der Lingen et al. 2009) and gobies feed mainly on zooplankton and zooplankton and jellyfish, respectively, but sardines are more omnivorous and are able to filter feed on phytoplankton when abundant (van der Lingen et al. 2009). Interestingly, however, gobies are substantially lighter in $\delta^{13} \mathrm{C}\left(\delta^{13} \mathrm{C} \approx-16.3 \%\right)$ compared to both sardines and anchovy (both $\delta^{13} \mathrm{C} \approx-13 \%$, C. D. van der Lingen \& T. Miller pers. comm.), which is likely due to the consumption of bacteria-rich sediment. A number of studies have shown that sulphur-bacteria have very depleted levels of $\delta^{13} \mathrm{C}$, ranging from -40 to $-26.1 \%$ (Levin \& Michener 2002, Gilhooly et al. 2007, Levin et al. 2009), and this impacts the structure of basal components of the food webs so based.

Although many higher predators within the Benguela ecosystem off Namibia have now replaced sardines in their diet with gobies (e.g. Crawford et al. 1985), it is clear that gobies have not assumed the role of sardines or anchovy within the system. Despite relatively slow growth rates and late maturity, a comparatively long life-span (Melo \& Le Clus 2005), and a high level of predation pressure, the regional biomass of Sufflogobius bibarbatus is increasing (Staby \& Krakstad 2006). Although its adaptations to a physiologically stressful environment are remarkable (Utne-Palm et al. 2010), its success within the altered ecosystem off Namibia must also reflect its flexible diet and an ability to use both the huge jellyfish biomass found there (Lynam et al. 2006) and the benthos. Indeed, by tapping into both of these (previously considered) deadend resources (Sommer et al. 2002, Heymans et al. 2004), the bearded goby provides a mechanism by which commercial fish biomass and production can be stabilised. It provides a key link in the food web off Namibia, and its populations should be managed accordingly.

The results generated in this study demonstrate the utility of using a suite of tracers in trophic studies. For example, the stable carbon and nitrogen isotope ratios indicate that jellyfish are an important dietary source for gobies, but that zooplankton and sediment are not. This is in contrast to the results of the fatty acid analyses, which do not strongly support a medusivorous diet (lipid concentrations in jellyfish are extremely low), but they do suggest that zooplankton are impor- 
tant for small gobies and that (sedimented) diatoms are more important for large gobies. The results of the stable sulphur isotope analyses indicate that diatom-, and sulphur bacteria-rich sediments are an important source of food for gobies, which is supported by the fatty acid data and (weakly) by the generally low (by comparison with pelagic fishes) levels of $\delta^{13} \mathrm{C}$ (see above). In other words, complementary, and supportive, information about the diet of the bearded goby are provided by the different types of analyses.

Acknowledgements. We thank our colleagues and the officers and crew of the RV 'G. O. Sars' for their assistance at sea, and colleagues in the Department of Archaeology at the University of Cape Town for assistance in the determination of carbon and nitrogen isotope ratios. We are grateful to C. D. van der Lingen (DAFF, South Africa) and T. Miller (Ehime University, Japan) for permission to present some of their unpublished data for sardine and anchovy, and we are grateful to the latter and to R. Brodeur (NW Fisheries Centre, USA) for their useful comments on an initial draft of the manuscript. Particular thanks are due to the 4 anonymous reviewers, whose comments have improved the readability of the text. M.v.d.B. acknowledges the Canon Collins Foundation and the National Research Foundation (NRF) for bursary support, whilst other grants were provided by the various home institutions and the South Africa-Norway Programme for Research Collaboration, funded jointly by the NRF and the Norwegian Research Council.

\section{LITERATURE CITED}

Arai MN (2005) Predation on pelagic coelenterates: a review. J Mar Biol Assoc UK 85:523-536

Arai MN, Welch DW, Dunsmuir AL, Jacobs MC, Ladouceur AR (2003) Digestion of pelagic Ctenophora and Cnidaria by fish. Can J Fish Aquat Sci 60:825-829

Bakun A, Weeks SJ (2006) Adverse feedback sequences in exploited marine systems: Are deliberate interruptive actions warranted? Fish Fish 7:316-333

Barber RT, Haedrich RL (1969) Gobies associated with a scattering layer off southwest Africa. Deep-Sea Res 16: 105-106

Bligh EG, Dyer WJ (1959) A rapid method of total lipid extraction and purification. Can J Biochem Physiol 37:911-917

Boyer DC, Hampton I (2001) An overview of the living marine resources of Namibia. S Afr J Mar Sci 23:5-35

Boyer DC, Boyer HJ, Fossen I, Kreiner A (2001) Changes in abundance of the northern Benguela sardine stock during the decade 1990-2000, with comments on the relative importance of fish and the environment. S Afr J Mar Sci 23:67-84

Budge SM, Parrish CC (1998) Lipid biogeochemistry of plankton, settling matter and sediments in Trinity Bay, Newfoundland. II. Fatty acids. Org Geochem 29:1547-1559

Budge SM, Iverson SJ, Koopman HN (2006) Studying trophic ecology in marine ecosystems using fatty acids: a primer on analysis and interpretation. Mar Mamm Sci 22:759-801

Buecher E, Sparks C, Brierley A, Boyer H, Gibbons M (2001) Biometry and size distribution of Chrysaora hysoscella (Cnidaria, Scyphozoa) and Aequorea aequorea (Cnidaria, Hydrozoa) off Namibia with some notes on their parasite Hyperia medusarum. J Plankton Res 23:1073-1080

Bunn SE, Loneragan NR, Kempster MA (1995) Effects of acid washing on stable isotope ratios of $\mathrm{C}$ and $\mathrm{N}$ in penaeid shrimp and seagrass: implications for food-web studies using multiple stable isotopes. Limnol Oceanogr 40: $622-625$

Cedras RB (2009) The diet and feeding ecology of the pelagic goby, Sufflogobius bibarbatus, off Namibia. MS thesis, University of the Western Cape, Cape Town

Clarke KR, Warwick RM (2001) Changes in marine communities: an approach to statistical analysis and interpretation. 2nd edn. PRIMER-E, Plymouth Marine Laboratory, Plymouth

Connolly RM, Guest MA, Melville AJ, Oakes JM (2004) Sulfur stable isotopes separate producers in marine food-web analysis. Oecologia 138:161-167

Crawford RLM, Cruickshank RA, Shelton PA, Kruger I (1985) Partitioning of a goby resource amongst four avian predators and evidence for altered trophic flow in the pelagic community of an intense, perennial upwelling system. S Afr J Mar Sci 3:215-228

- Cury P, Shannon L (2004) Regime shifts in upwelling ecosystems: observed changes and possible mechanisms in the northern and southern Benguela. Prog Oceanogr 60: $223-243$

D'Arcangues C (1977) Sound-scattering layers in neritic waters off south-west Africa. Ann Inst Oceanogr 53: 87-104

Dale AW, Brüchert V, Alperin M, Regnier P (2009) An integrated sulfur isotope model for Namibian shelf sediments. Geochim Cosmochim Acta 73:1924-1944

del Norte-Campos AGC, Temmings A (1994) Daily activity, feeding and rations in gobies and brown shrimp in the northern Wadden Sea. Mar Ecol Prog Ser 115:41-53

Demopoulos AWJ, Fry B, Smith CR (2007) Food web structure in exotic and native mangroves: a Hawaii-Puerto Rico comparison. Oecologia 153:675-686

DeNiro MJ, Epstein S (1977) Mechanism of carbon isotope fractionation associated with lipid synthesis. Science 197: 261-263

> El-Sabaawi RW, Sastri AR, Dower JF, Mazumber A (2010) Deciphering the seasonal cycle of copepod trophic dynamics in the Strait of Georgia, Canada, using stable isotopes and fatty acids. Estuar Coasts 33:738-752

- Flynn BA, Gibbons MJ (2007) A note on the diet and feeding of Chrysaora hysoscella in Walvis Bay Lagoon, Namibia, during September 2003. Afr J Mar Sci 29:303-307

- France RL, Peters RH (1997) Ecosystem differences in the trophic enrichment of ${ }^{13} \mathrm{C}$ in aquatic food webs. Can J Fish Aquat Sci 54:1255-1258

Fréon P, Arístegui J, Bertrand A, Crawford RJM and others (2009) Functional group biodiversity in Eastern Boundary Upwelling Ecosystems questions the wasp-waist trophic structure. Prog Oceanogr 83:97-106

Gibson RN (1970) Observations on the biology of the giant goby Gobius cobitis Pallas. J Fish Biol 2:281-288

Gilhooly WP III, Carney RS, Macko SA (2007) Relationships between sulphide-oxidizing bacterial mats and their carbon sources in northern Gulf of Mexico cold seeps. Org Geochem 38:380-393

Gordoa A, Macpherson E, Olivar MP (1995) Biology and fisheries of Namibian hakes (M. paradoxus and M. capensis). In: Alheit J, Pitcher TJ (eds) Hake: biology, fisheries and markets. Chapman \& Hall, London, p 49-88

> Graeve M, Kattner G, Hagen W (1994) Diet-induced changes in the fatty acid composition of Arctic herbivorous copepods: experimental evidence of trophic markers. J Exp Mar Biol Ecol 182:97-110

Grossman GD (1980) Ecological aspects of ontogenetic shifts 
in prey size utilization in the bay goby (Pisces: Gobiidae). Oecologia 47:233-238

Grossman GD, Coffin R, Moyle PB (1980) Feeding ecology of the bay goby (Pisces: Gobiidae). Effects of behavioural, ontogenetic, and temporal variation on diet. J Exp Mar Biol Ecol 44:47-59

> Heymans JJ, Shannon LJ, Jarre A (2004) Changes in the northern Benguela ecosystem over three decades: 1970s, 1980s and 1990s. Ecol Model 172:175-195

Hobson KA, Ambrose WG Jr, Renaud PE (1995) Sources of primary production, benthic-pelagic coupling and trophic relationships within the Northeast Water Polynya: insights from $\delta^{13} \mathrm{C}$ and $\delta^{15} \mathrm{~N}$ analysis. Mar Ecol Prog Ser 128:1-10

Hobson KA, Gloutney ML, Gibbs HL (1997) Preservation of blood and tissue samples for stable-carbon and stablenitrogen isotope analysis. Can J Zool 75:1720-1723

Hundt M (2009) Diel feeding behaviour of Sufflogobius bibarbatus under hypoxic conditions in the northern Benguela region. MS thesis, University of Bergen

> Jacq E, Prieur D, Nichols P, White DC, Porter T, Geesey GG (1989) Microscopic examination and fatty acid characterization of filamentous bacteria colonizing substrate around subtidal hydrothermal vents. Arch Microbiol 152:64-71

> Lebrato M, Jones DOB (2009) Mass deposition event of Pyrosoma atlanticum carcasses off Ivory Coast (West Africa). Limnol Oceanogr 54:1197-1209

> Levin LA, Michener RH (2002) Isotopic evidence for chemosynthesis-based nutrition of macrobenthos: the lightness of being at Pacific methane seeps. Limnol Oceanogr 47:1336-1345

> Levin LA, Mendoza GF, Konotchick T, Lee R (2009) Macrobenthos community structure and trophic relationships within active and inactive Pacific hydrothermal sediments. Deep-Sea Res II 56:1632-1648

Levy D (1990) Sensory mechanism and selective advantage for diel vertical migration in juvenile sockeye salmon, Oncorhynchus nerka. Can J Fish Aquat Sci 47:1796-1802

Lynam CP, Gibbons MJ, Axelsen BE, Sparks CAJ, Coetzee J, Heywood BG, Brierley AS (2006) Jellyfish overtake fish in heavily fished ecosystems. Curr Biol 16:R492-R493

Macpherson E, Roel BA (1987) Trophic relationships in the demersal fish community off Namibia. S Afr J Mar Sci 5: 585-596

> Maruyama A, Yamada Y, Rusuwa B, Yuma M (2001) Stable nitrogen and carbon isotope ratios as migration tracers of a landlocked goby, Rhinogobius sp. (the orange form), in the Lake Biwa water system. Ecol Res 16:697-703

McCaffrey MA, Farrington JW, Repeta DJ (1989) Geochemical implication of the lipid composition of Thioploca spp. from the Peru upwelling region $-15^{\circ} \mathrm{S}$. Org Geochem 14:61-68

McCutchan JHJ, Lewis WM, Kendall C, McGrath CC (2003) Variation in trophic shift for stable isotope ratios of carbon, nitrogen, and sulfur. Oikos 102:378-390

Melo YC, Le Clus F (2005) Growth and reproduction of the pelagic goby Sufflogobius bibarbatus off the Orange River, southern Africa. S Afr J Mar Sci 27:265-273

Minagawa M, Wada E (1984) Stepwise enrichment of ${ }^{15} \mathrm{~N}$ along food chains: further evidence and the relation between $\delta^{15} \mathrm{~N}$ and animal age. Geochim Cosmochim Acta 48:1135-1140

Monteiro PMS, van der Plas A, Mohrholz V, Mabille E, Pascall A, Joubert W (2006) Variability of natural hypoxia and methane in a coastal upwelling system: oceanic physics or shelf biology. Geophys Res Lett 33:L16614 doi:10.1029/ 2006GL026234
O'Toole MJ (1978) Development, distribution and relative abundance of the larvae and early juveniles of the pelagic goby Sufflogobius bibarbatus (von Bonde) off South West Africa 1972-1974. Sea Fish Branch Invest Rep 116:1-28

Parrish CC, Abrajano TA, Budge SM, Helleur RJ, Hudson ED, Pulchan K, Ramos C (2000) Lipid and phenolic biomarkers in marine ecosystems: analysis and applications. In: Wangersky PJ (ed) The handbook of environmental chemistry, Vol 5, Part D. Springer, Berlin, p 193-223

Pauly D, Christensen V, Dalsgaard J, Froese R, Torres F Jr (1998) Fishing down marine food webs. Science 279: 860-863

Peterson BJ, Fry B (1987) Stable isotopes in ecosystem studies. Annu Rev Ecol Syst 18:293-320

Phillips DL, Gregg JW (2003) Source partitioning using stable isotopes: coping with too many sources. Oecologia 136: 261-269

Pitt KA, Clement A, Connolly RM, Thibault-Botha D (2007) Predation by jellyfish on large and emergent zooplankton: implications for benthic-pelagic coupling. Estuar Coast Shelf Sci 4:827-833

Pitt KA, Connolly RM, Meziane T (2009) Stable isotope and fatty acid tracers in energy and nutrient studies of jellyfish: a review. Hydrobiologia 616:119-132

Quinn G, Keough M (2002) Experimental design and data analysis for biologists. Cambridge University Press, Cambridge, p 32-54

Rossi F, Herman PMJ, Middelburg JJ (2004) Interspecific and intraspecific variation of $\delta^{13} \mathrm{C}$ and $\delta^{15} \mathrm{~N}$ in deposit- and suspension feeding bivalves (Macoma balthica and Cerastoderma edule): evidence of ontogenetic changes in feeding mode of Macoma balthica. Limnol Oceanogr 49: 408-414

Sargent JR, Falk-Petersen S (1988) The lipid biochemistry of calanoid copepods. Hydrobiologia 167-168:101-114

Schulz HN, Brinkhoff T, Ferdelman TG, Hernández Mariné M, Teske A, Jørgensen BB (1999) Dense populations of a giant sulfur bacterium in Namibian shelf sediments. Science 284:493-495

- Sommer U, Stibor H, Katechakis A, Sommer F, Hansen T (2002) Pelagic food web configurations at different levels of nutrient richness and their implications for the ratio fish production:primary production. Hydrobiologia 484:11-20

Sorensen PW, Hobson KA (2005) Stable isotope analysis of amphidromous Hawaiian gobies suggests their larvae spend a substantial period of time in freshwater river plumes. Environ Biol Fishes 74:31-42

Sparks C, Buecher E, Brierley AS, Axelsen BE, Boyer $H$, Gibbons MJ (2001) Observations on the distribution and relative abundance of the scyphomedusan Chrysaora hysoscella (Linnè, 1766) and the hydrozoan Aequorea aequorea (Forskål, 1775) in the northern Benguela ecosystem. Hydrobiologia 451:275-286

Staby A, Krakstad JO (2006) Review of the state of knowledge, research (past and present) of the distribution, biology, ecology and abundance of non-exploited mesopelagic fish (Order Anguilliformes, Argentiniformes, Stomiiformes, Myctophiformes, Aulopiformes) and the bearded goby (Sufflogobius bibarbatus) in the Benguela Ecosystem. Report on BCLME project LMR/CF/03/08. Available at www.bc/me.org/projects/docs/LMR-CF-0308.pdf (accessed April 2011)

> Struck U, Altenbach AV, Emeis K, Alheit J, Eichner C, Schneider R (2002) Changes of the upwelling rates of nitrate preserved in the $\delta^{15} \mathrm{~N}$-signature of sediments and fish scales from the diatomaceous mud belt of Namibia. Geobios 35: $3-11$

Taylor J, Parkes RJ (1983) The cellular fatty acids of the sul- 
phate-reducing bacteria Desulfobacter sp. Desulfobulbus sp. and Desulfovibrio desulfuricans. J Gen Microbiol 129: 3303-3309

> Thomas CJ, Cahoon LB (1993) Stable isotope analyses differentiate between different trophic pathways supporting rocky-reef fishes. Mar Ecol Prog Ser 95:19-24

- Towanda T, Thuesen EV (2006) Ectosymbiotic behaviour of Cancer gracilis and its trophic relationships with its host Phacellophora camtschatica and the parasitoid Hyperia medusarum. Mar Ecol Prog Ser 315:221-236

> Utne-Palm AC, Salvanes AGV, Currie B, Kaartvedt S and others (2010) Trophic structure and community stability in an overfished ecosystem. Science 329:333-336

van der Lingen $C D$, Bertrand A, Bode A, Brodeur R and

Editorial responsibility: Nicholas Tolimieri, Seattle, Washington, USA others (2009) Trophic dynamics. In: Checkley D, Alheit J, Oozeki Y, Roy C (eds) Climate change and small pelagic fish. Cambridge University Press, Cambridge, p 112-157

Zar JH (1999) Biostatistical analysis, 4th edn. Prentice-Hall, Upper Saddle River, NJ

Zhang CL, Li Y, Wall JD, Larsen L and others (2002) Lipid and carbon isotopic evidence of methane-oxidizing and sulphate-reducing bacteria in association with gas hydrates from the Gulf of Mexico. Geology 30:239-242

Zhang CL, Huang Z, Cantu J, Pancost RD, Brigmon RL, Lyons TW, Sassen R (2005) Lipid biomarkers and carbon isotope signatures of a microbial (Beggiatoa) mat associated with gas hydrates in the Gulf of Mexico. Appl Environ Microbiol 71:2106-2112

Submitted: August 30, 2010; Accepted: February 7, 2011 Proofs received from author(s): April 21, 2011 